\title{
Oncogenic Ras Induces Gastrin Gene Expression in Colon Cancer
}

\author{
HIROHISA NAKATA,* SHU-LI WANG,* DANIEL C. CHUNG ${ }^{\ddagger}$ JOHN K. WESTWICK, $*$, \\ and LOYAL G. TILLOTSON* \\ * Division of Digestive Diseases and Nutrition, Department of Medicine, University of North Carolina, Chapel Hill, North Carolina; \\ ‡Gastrointestinal Unit, Massachusetts General Hospital, Boston, Massachusetts; and §Signal Pharmaceuticals, Inc., San Diego, California
}

Background \& Aims: The expression of gastrin, as a tumor growth factor, is significantly increased in some colon cancers compared with the low levels found in normal mucosa. The aim of this study was to elucidate the transcriptional mechanisms of gastrin induction in colon cancer. Methods: Gastrin messenger (mRNA) levels and $\mathrm{K}$-ras genotype were determined in colon cancer cell lines and surgical specimens. Colon cancer cells were transfected with oncogenic ras expression vectors, and transcriptional activity was assayed with gastrin-luciferase reporter genes. Results: Colon cancer cell lines and tissues with K-ras mutations all had significantly higher gastrin mRNA levels than those that were ras wild type. Treatment of several ras mutant cell lines with PD98059, an inhibitor of mitogen-activated protein kinase kinase, resulted in a decrease in endogenous gastrin mRNA levels. The effects of ras on gastrin expression appeared to be mediated through the gastrin promoter because transfection of oncogenic ras and activated raf expression vectors both induced gastrin-promoter, luciferase-reporter genes. The inductive effects of oncogenic ras could be blocked by the coexpression of dominant negative forms of raf and extracellular regulated kinase. Conclusions: Oncogenic ras induces gastrin gene expression through activation of the Raf-MEK-ERK signal transduction pathway.

G astrin, a peptide hormone and trophic factor, has long been recognized to stimulate mucosal growth in the upper digestive tract.1,2 More recent findings suggest that gastrin has proliferative effects in colon cancer as well. M any studies have shown that exogenously administered gastrin stimulated the growth and prol iferation of colon cancer cells in culture, ${ }^{3,4}$ transplanted colon tumors in mice, ${ }^{5}$ and carcinogen-induced tumors in rats. ${ }^{6}$ In addition, antagonism of gastrin effects by antigastrin antisera, ${ }^{7,8}$ gastrin receptor antagonists, ${ }^{3,9,10}$ and antisense gastrin RNA ${ }^{11}$ inhibited growth of colon cancer cells in culture and in vivo animal models. There is some controversy about whether gastrin acts on col on cancer by hormonal mechanisms through circulating processed gastrin or through autocrine effects of locally produced, incompletely processed gastrin. ${ }^{12}$ Both forms of gastrin have proliferative effects on colonic mucosa, ${ }^{13}$ but most colon tumors that produce gastrin express the incompletely processed, glycine-extended form. ${ }^{14-16}$

In the normal colon, gastrin expression is greatest during fetal development and then decreases to a very low level from birth through maturity. ${ }^{17}$ Some col on cancers, but not all, have increased levels of gastrin message compared with normal mucosa. ${ }^{14,18} \mathrm{Although}$ there is not much information about what factors induce gastrin expression, some evidence shows that transforming growth factor $\alpha$ (TGF- $\alpha)$ and epidermal growth factor (EGF) stimulate gastrin transcriptional activity in several colon and pituitary cell lines. ${ }^{19,20}$ It is well established that many tumors express autocrine growth factors, but the signaling cascades initiated and transcriptional mechanisms involved are poorly characterized, ${ }^{21,22}$ including those responsible for gastrin induction in colon cancer.

The Ras-Raf signal transduction pathway, which is frequently involved in oncogenesis, plays a critical rolein regulating genes involved in growth and proliferation. ${ }^{23-25}$ Although there is clear evidence that oncogenic $R$ as can have transforming effects that are $R$ af independent, ${ }^{26}$ it is the Ras-Raf-MEK-ERK pathway that responds to mitogens such as EG ${ }^{27}$ and also regulates the expression of growth factors, such as TGF- $\alpha^{28}$ and heparin-binding EGF. ${ }^{29}$ Such cases suggest that an autocrine loop can involve Ras signaling and tumor growth factor expression. To determine if there was a correlation between oncogenic activation of $\mathrm{R}$ as and gastrin expression, a panel of human colon cancer cell

Abbreviations used in this paper: EGF, epidermal growth factor; $P C R$, polymerase chain reaction; RPA, ribonuclease protection assay; SDS, sodium dodecyl sulfate; SSC, standard saline citrate; TGF- $\boldsymbol{\alpha}$, transforming growth factor $\boldsymbol{\alpha}$.

(1) 1998 by the American Gastroenterological Association $0016-5085 / 98 / \$ 3.00$ 
lines and several tissue specimens were examined for gastrin expression, ras status, and Ras-Raf pathway activity.

\section{Materials and Methods}

\section{Cell Lines and Tissues}

All cell lines were obtained from the American Type Culture Collection (M anassas, VA). Cells were cultured in the following media: RPMI 1640 (Colo320H SR and Colo205), Dulbecco's modified Eagle medium with high glucose (H T29, H ct116, Caco-2, and LoVo), and Leibovitz's L-15 (SW 480), each supplemented with 10\% fetal bovine serum (BioW hittaker, Walkersville, MD) and $2 \%$ penicillin/streptomycin $(10,000 \mathrm{U} / \mathrm{mL})$. Surgical specimens were snap-frozen on resection and stored at $-80^{\circ} \mathrm{C}$. Treatment of cells with the MEK inhibitor PD 98059 (Cal biochem, La J olla, CA) was as follows. Cells were plated in complete media (plus fetal bovine serum) at an approximate density of $70 \%$ confluency. After 12 hours, the media were changed to serum-free media with 10 or 100 $\mu \mathrm{mol} / \mathrm{L}$ PD 98059 (0.5\% dimethyl sulfoxide) or diluent alone ( $0.5 \%$ dimethyl sulfoxide). Cells were harvested 36 hours later for RNA and protein extraction. Cells appeared to tolerate PD 98059 treatment well such that, at the time of harvest, there was no significant difference in cell number or morphology from the control cells (diluent treatment). Thirty-six hours of PD98059 treatment was chosen for maximal effect on gastrin messenger RNA (mRN A) levels because there was no significant change after 12 hours and moderate change after 24 hours.

\section{Ribonuclease Protection Assay}

Riboprobes were generated from antisense templates from human gastrin exon 2 (nucleotide 304 digested to nucleotide 210), human gastrin exon 1 and $5^{\prime}$-flanking sequence (nucleotide 109 digested to nucleotide 56), and human cyclophilin (nucleotide 170 digested to nucleotide 103). Riboprobes were prepared by in vitro transcription (Riboprobe System; Promega, Madison, WI) incorporating $\left[\alpha^{32} \mathrm{P}\right]$ cytidinetriphosphate $(800 \mathrm{Ci} / \mathrm{mmol}$; A mersham, Arlington $\mathrm{H}$ eights, IL). Probes were isol ated after urea gel el ectrophoresis and extraction (shaking in $300 \mathrm{mmol} / \mathrm{L}$ sodium acetate, $0.1 \mathrm{mmol} / \mathrm{L}$ EDTA, and $0.2 \%$ sodium dodecyl sulfate [SDS] at $50^{\circ} \mathrm{C}$ for 2 hours). Total RN A preparation was performed by a standard guanidine isothiocyanate, phenol extraction method. ${ }^{30}$ For the ribonuclease protection assay (RPA), ${ }^{31}$ both gastrin $\left(1 \times 10^{6} \mathrm{cpm}\right)$ and cyclophilin $\left(1 \times 10^{4} \mathrm{cpm}\right)$ riboprobes were combined with $150 \mu \mathrm{gg}$ of total RNA in each reaction and hybridized for 16 hours at $57^{\circ} \mathrm{C}(1 \mathrm{mmol} / \mathrm{L}$ EDTA; $40 \mathrm{mmol} / \mathrm{L}$ pi perazine $\mathrm{N}, \mathrm{N}$ '-bis(2-ethanesulfonic acid), $\mathrm{pH} 6.4 ; 400 \mathrm{mmol} / \mathrm{L} \mathrm{NaCl}$; and $80 \%$ formamide). Both riboprobes were added to each assay to control for RNA integrity and quantification. A fter hybridization, samples were digested with ribonuclease $\mathrm{A}(20 \mu \mathrm{g} / \mathrm{mL})$ and ribonuclease $\mathrm{T} 1$

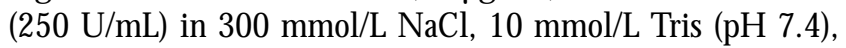
and $5 \mathrm{mmol} / \mathrm{L}$ EDTA at $37^{\circ} \mathrm{C}$ for 30 minutes. After the digestion was stopped, RN A was precipitated and resolved by denaturing gel electrophoresis. Densitometry was determined from digitally scanned radiographs, and results were normalized to cyclophilin levels. Because cyclophilin message was so abundant, approximately 10 -fold less cyclophilin probe was used in Figure 1A .

\section{K-ras Genotyping}

Polymerase chain reaction (PCR)-amplified $\mathrm{K}$-ras gene fragments were prepared from each of the cell lines and tissues. Analysis of the K -ras genotype at codons 12, 13, and 61 was accomplished by two methods: slot blot Southern hybridization and DNA sequencing of subcloned PCR products. Genomic DNA was extracted from each sample according to standard methods ${ }^{31}$ and digested with ECOR 1. PCR was performed by a standard method incorporating Taq polymerase (Perkin-Elmer Corp., N orwalk, CT) with 5\% formamide added to the reaction ( $35 \mathrm{cycles}$ of $80^{\circ} \mathrm{C}$ for 20 seconds, $48^{\circ} \mathrm{C}$ for 20 seconds, and $72^{\circ} \mathrm{C}$ for 30 seconds). H uman $\mathrm{K}$-ras primers were as follows: codon 12-F, 5'-ATGACTGAATATAAACTTGT; codon 12-R, 5'-CGTCCACAAAATGATTCTG; codon 61-F, 5'-TTCCTACAGGAAGCAAGTAG; and codon 61-R, 5'CACAAAGAAAGCCCTCCCCA.

\section{Southern Hybridization Analysis}

Five hundred nanograms of DNA product from each reaction was denatured and transferred to $\mathrm{N}$ ytran membranes (Schleicher \& Schuell, Keene, NH) for slot blot Southern hybridization. ${ }^{32} \mathrm{P}$-labeled oligonucleotide probes encompassing codons 12 and 13 , containing mutations in each codon respectively for glycine (wild type), cysteine, serine, arginine, valine, aspartate, and alanine, were used for hybridization. A fter the blots were pretreated with buffer $(5 \times$ standard sal ine citrate [SSC], $1 \% \mathrm{SDS}$, and $0.2 \%$ nonfat dried milk), ${ }^{31}$ probe was added and incubated at $65^{\circ} \mathrm{C}$ for 16 hours. Blots were washed in several changes of $0.2 \times \mathrm{SSC}$ and $0.1 \%$ SD S at $61^{\circ} \mathrm{C}$ and autoradiographed. Codon 61 PCR products were not analyzed by this method.

\section{DNA Sequence Analysis}

PCR products were purified by agarose gel el ectrophoresis and subcloned into PGEM - T vector (Promega) by standard methods. For each sample, dideoxy sequencing confirmed the genotype identified in the slot blot assays. Codon 61 PCR products from ColoH SR, Colo205, HT29, and Caco-2 were subcloned and sequenced.

\section{Statistical Analysis}

Statistical analysis of gastrin RPA and ras status used a Mann-W hitney test for thecentral tendency of two distributions.

\section{ERK Assay}

ERK activity was determined by an in vitro immune complex kinase assay 32 with recombinant GST-Elk as the substrate. ${ }^{33}$ Protein A sepharose and anti-ER K 2 antisera (C14; Santa Cruz Biotechnology, Santa Cruz, CA), which can also 

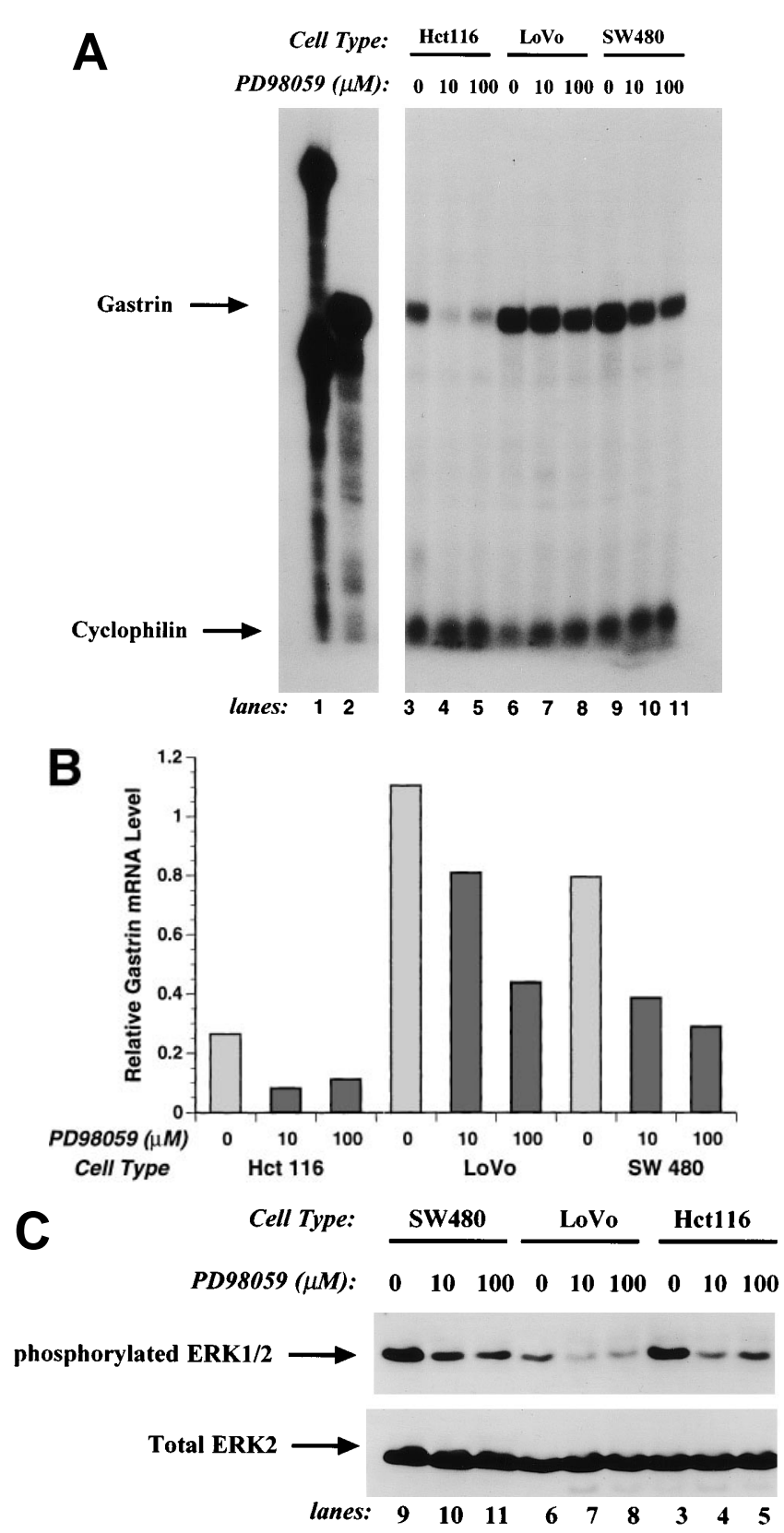

Figure 1. (A) RPA of colon cancer cells treated with the MEK inhibitor PD98059. Hct116, LoVo, and SW480 cells were treated for 36 hours with or without inhibitor and subjected to RPA as described in Materials and Methods. Digested gastrin and cyclophilin riboprobes are indicated by the arrows. The undigested probes are shown in lane 1 , and the positive control for gastrin message is shown in lane 2. $(B)$ Relative gastrin mRNA levels in cells treated with or without PD98059. Densitometry of gastrin and cyclophilin mRNA levels from RPA $(A)$ with results normalized to cyclophilin message levels. (C) Western blot of phosphorylated and total ERK1,2 from colon cancer cells treated with the MEK inhibitor PD98059. Protein extracts (100 $\mu \mathrm{g}$ each) from cells treated for 36 hours with PD98059 or diluent were resolved by $10 \%$ SDS-PAGE and blotted as described in Materials and Methods. Lane numbers refer to the same lanes in $A$. Western blot with antisera and chemiluminescent detection was as described in Materials and Methods. cross-react with ERK 1, were used to immunopreci pitate ERK s from equivalent amounts of whole-cell extracts. After washing the immune complexes, $\left[\gamma^{-32}\right.$ ] adenosine triphosphate and recombinant GST-Elk were then added for the kinase reaction. The reaction products were resolved by $10 \%$ SD S gel electrophoresis and were autoradiographed.

\section{Western Blot Analysis}

ERK 1,2 and phosphorylated ERK 1,2 levels were determined by W estern blot analysis. Equivalent amounts of protein $(100 \mu \mathrm{g})$ from whole-cell extracts were resolved by $10 \%$ SDS-polyacrylamide gel electrophoresis (PAGE) and electrotransferred to polyvinylidene difluoride membranes (Tropifluor; Tropix, Bedford, MA). After blocking nonspecific binding (I-block; Tropix), blots were probed with anti-ER K 2 (C14; Santa Cruz) or antiphosphorylated ERK 1,2 (Anti-Active M APK $\mathrm{pAb}$; Promega) antisera. Both antisera are cross-reactive with p44 ERK 1 and p42 ERK 2. After probing with the primary antisera, blots were washed and probed with anti-rabbit antisera conjugated with alkal ine phosphatase. The blots were developed with CDP-Star chemiluminescent reagent (Tropix).

It should be noted that p44 ERK 1 was not electrophoretically resolved from p42 ERK 2 . H ence, ERK 1,2 migrated as a single complex. Adjusting the electrophoretic conditions in subsequent confirmatory experiments did achieve resolution of two bands, which when probed with the Anti-Active MAPK antisera showed that both had equival ent degrees of phosphorylation (data not shown).

\section{Transfection and Transcriptional Analysis}

Colo H SR cells were plated in six-well plates (Falcon; Becton Dickinson, Lincoln Park, $\mathrm{NJ}$ ) at approximately $70 \%$ confluency in complete media (RPMI $1640+10 \%$ fetal bovine serum and $2 \%$ penicillin/streptomycin). Cells were transfected 12 hours later by a standard $\mathrm{CaPO}_{4}$ technique, ${ }^{31}$ and the media were changed to RPMI 1640 supplemented with $0.5 \%$ fetal bovine serum. Cells were harvested at 48 hours for luciferase $\mathrm{e}^{34}$ and protein ${ }^{35}$ assays. Typically, $1 \mu \mathrm{g}$ of reporter plasmid and $0.25-0.5 \mu \mathrm{g}$ of expression plasmid were transfected in each $35-\mathrm{mm}$ well. Construction of gastrin promoter plasmids, 200 GasLuc and 1300 GasLuc, which denote the length of 5'-flanking sequence, has been reported previously. ${ }^{36}$ The luciferase reporter plasmids $p(P y) 2$ Luc, ${ }^{37}$ pG L Col3 Luc, ${ }^{38}$ and pT 81 Luc $^{39}$ have been described previously. Expression plasmids, including pZip $\mathrm{H}-\mathrm{ras}_{61 \mathrm{~L}}$ and pZip neo, ${ }^{40}$ pZip rafCAAX, ${ }^{26}$ pZip R aC ${ }_{17 \mathrm{~N}}$, and pZip R ho ${ }_{19 \mathrm{~N}},{ }^{41} \mathrm{pVL} \mathrm{raf}_{301},{ }^{42}$ and PCMV ERK $1,2_{K M}$, 43 have been described previously. Internal transfection standards were not used, but rather luciferase assays were checked for equival ent protein concentrations. Data were derived from the mean of triplicate transfected wells, and transfection experiments were repeated three to four times each.

\section{Results}

\section{Gastrin mRNA Levels in Colon Cancer}

A sensitive RPA was developed for the detection and quantification of gastrin mRNA levels in colon 
cancer cell lines and tissue samples obtained from surgical resection. Antisense riboprobes derived from human gastrin (exon 2) and cyclophilin gene templates were used in each assay. Cyclophilin mRNA, transcribed from a ubiquitous housekeeping gene, served as an internal control for mRNA integrity and reaction conditions. Total R N A samples from seven col on cancer cell lines and two pairs of human tissue samples were used for the R PA shown in Figure 2A. Undigested gastrin and cyclophilin riboprobes are present in lane 17. Lanes 1 and 2 contain reactions from a positive gastrin message control and a negative control (transfer R N A only), respectively. Gastrin $\mathrm{mRN} A$ was readily detectablein total RN A prepared from SW 480, HT29, H ct116, and LoVo cells but was barely discernible in Colo205, ColoH SR, and Caco-2 cells.

Tissue specimens from two colon cancers and their paired normal margins were assayed by gastrin and cyclophilin R PA. Tumor 1 (T1) had significantly el evated gastrin mRNA levels compared with its normal margin tissue (N 1). Tumor 2 (T2) had undetectable gastrin message, as did its normal margin (N 2). Additional tissue specimens from 9 other colon cancers were assayed by gastrin and cyclophilin RPA as shown in Figure 2B. Gastrin mRNA levels were el evated in tumors T3, T4, T6, T8, and T11. Relative amounts of gastrin and cyclophilin mRN As were determined from both RPA s by densitometry. The cyclophilin mR N A levels werenormal-
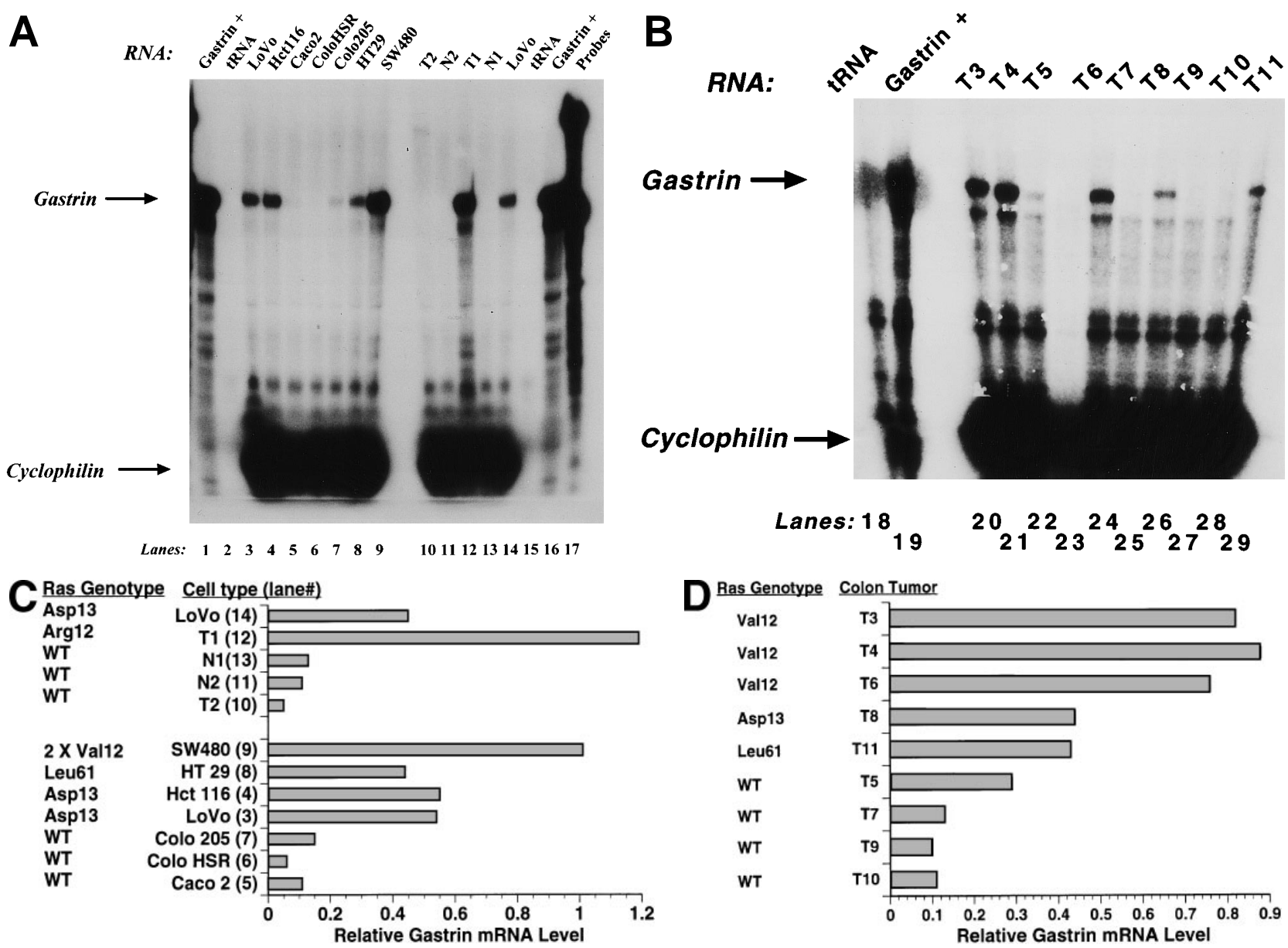

Figure 2. (A) RPA for gastrin and cyclophilin message. Total RNA ( $150 \mu \mathrm{g}$ each reaction) was hybridized with gastrin and cyclophilin riboprobes and digested as described in Materials and Methods. Digested products are indicated with the arrows. Samples were as follows: lanes 3 and 14 , LoVo; lane 4, Hct116; lane 5, Caco-2; lane 6, ColoHSR; lane 7, Colo205; lane 8, HT29; lane 9, SW480; lane 10, tumor 2; lane 11, margin 2; lane 12, tumor 1; lane 13, margin 1; lanes 2 and 15, transfer RNA tRNA; lanes 1 and 16, human gastrin mouse transgene; and lane 17, undigested probes. (B) RPA for gastrin and cyclophilin message in colon cancer specimens. Total RNA (150 $\mu \mathrm{g}$ each reaction) was hybridized with gastrin and cyclophilin riboprobes and digested as described in Materials and Methods. Digested products are indicated with the arrows. Samples were as follows: lane 18, transfer RNA; lane 19, human gastrin mouse transgene; lane 20, tumor 3; lane 21, T4; lane 22, T5; lane 24, T6; lane 25, T7; lane 26, T8; lane 27, T9; lane 28, T10; and lane 29, T11. Of note, lane 18 (transfer RNA control) had a gel artifact of smeared signal from the adjacent lane, and the sample in lane 23 had degraded RNA. $(C)$ Gastrin mRNA levels relative to normalized cyclophilin mRNA. Densitometry of RPA $(A)$ with results normalized to cyclophilin message levels. A was scanned, and densities were determined for gastrin message levels. A shorter exposure of the radiograph for $A$ was used to determine cyclophilin signal densities. K-ras genotypes for each sample are listed (see Table 1). wT, wild type. $(D)$ Gastrin mRNA levels relative to normalized cyclophilin mRNA of colon cancer specimens. Densitometry of RPA (B) with results normalized to cyclophilin message levels. K-ras genotypes for each sample are listed (see Table 1). 
ized across the samples, and gastrin-relative-to-cyclophilin levels were determined for each sample and plotted as shown in Figure $2 C$ and $D$. A $>20$-fold range in relative gastrin expression was observed between the low-expressing ColoHSR cells and the high-expressing SW 480 cells. The results from the surgical samples indicate that, although gastrin expression is typically very low in normal adult colon tissue, it can be significantly el evated in some but not all col on tumors.

Determination of the transcriptional start site was done by hybridization of RN A from several col on cancer cell lines with a riboprobe prepared from a template of human gastrin exon 1 and additional 5'-flanking sequence. This RPA yielded protected fragments identical in length to those obtained from human gastric antral R N A (data not shown), confirming that gastrin mRN A expression in col on cancer occurs from the sametranscriptional start site as has been described in other tissues. ${ }^{44,45}$

\section{K-ras Genotypes}

$\mathrm{K}$-ras genotypes were determined from PCRamplified DNA of each of the cell lines and tissue samples. Mutations in $\mathrm{K}$-ras codons 12, 13, and 61 were detected by a combination of al lel e-specific hybridization and sequencing cloned PCR-amplified regions of the $\mathrm{K}$-ras gene. R esults of ras genotyping are shown in Table 1. Tumors T1, T3, T4, T6, T8, and T11, as well as SW 480, HT29, LoVo, and H ct116 cell lines were found to have oncogenic $K$-ras mutations. In contrast, Colo205, Caco-2, and ColoH SR cells; tumors T2, T5, T7, T9, and T10; and both normal colon margin tissues were wild

Table 1. K-ras Genotypes of Colon Cancer Cell Lines and Surgical Tissue Samples: Confirmation of Southern Oligonucleotide Hybridization by DNA Sequencing

\begin{tabular}{lcl}
\hline Sample & Codon (mutation) & \multicolumn{1}{c}{ Genotype } \\
\hline Hct116 & 13 (GAC) & ${ }^{13} \mathrm{Asp}$ \\
LoVo & $13(\mathrm{GAC})$ & ${ }^{13} \mathrm{Asp}$ \\
HT29 & 61 (CTA) & ${ }^{11} \mathrm{Leu}$ \\
SW480 & $12(\mathrm{GTT})$ & ${ }^{12} \mathrm{Val}$ homozygous \\
T1 & 12 (CGT) & ${ }^{12} \mathrm{Arg}$ \\
T3 & $12(\mathrm{GTT})$ & ${ }^{12} \mathrm{Val}$ \\
T4 & $12(\mathrm{GTT})$ & ${ }^{12} \mathrm{Val}$ \\
T6 & $12(\mathrm{GTT})$ & ${ }^{12} \mathrm{Val}$ \\
T8 & $13(\mathrm{GAC})$ & ${ }^{13} \mathrm{Asp}$ \\
T11 & 61 (CTA) & $61 \mathrm{Leu}$ \\
Caco-2 & & WT \\
ColoHSR & & WT \\
Colo205 & & WT \\
N1 & & WT \\
T2 & & WT \\
N2 & & WT \\
T5 & & WT \\
T7 & & WT \\
T9 & & WT \\
T10 & & WT \\
\hline
\end{tabular}

WT, wild type. type. Of note, HT29 cells and tumor T11 were found to have an oncogenic mutation in codon 61 (GIn $>$ Leu), which is unusual for K-ras. Previous reports of HT29 having wild-type $\mathrm{K}$-ras were based on sequencing just the codon $12 / 13$ region. ${ }^{46,47}$ All samples with ras mutations were heterozygous with a normal allele, with the exception of SW 480 which had homozygous ras mutations and no detectable normal allele. In each case, the sequence data confirmed the results from the allele-specific oligonucl eotide hybridization blots. Comparison of the results from the gastrin RPA and ras genotyping shows that the samples possessing ras mutations also have the highest gastrin mRNA levels with no overlap between the two groups ( $P=0.002)$. Interestingly, of the cell lines with oncogenic ras mutations, the only one that was homozygous, SW 480, had the highest expression of gastrin. These findings suggest a direct correlation between oncogenic activation of ras and induction of gastrin gene expression.

\section{ERK Activity and Phosphorylation}

ERK activity was assessed to determine if the cell lines and tissues with oncogenic ras mutations have an activated Ras-Raf signal transduction pathway. ERK, which was immunoprecipitated from the cell extracts, was incubated with recombinant GST-Elk protein, a substrate for the kinase enzyme. Phosphorylated GST-EIk was electrophoretically resolved, and the results of the assay are shown in Figure $3 \mathrm{~A}$. Densitometry of the GST-Elk complex is shown in Figure 3B. With the exception of Colo205 (lane 6), ras mutant cell lines had greater ERK activity than the wild-type cell lines ColoH SR and Caco-2. Among the tissue samples, only the ras mutant tumor 1 (T1) had significantly el evated ERK activity, whereas the other ras wild-type tumor sample (T2) was comparable to the normal margin tissue. It is notable that all of the samples appeared to have equival ent amounts of total ERK 1,2, as determined by Western blot (Figure $3 \mathrm{C}$ ). These assays suggest that, although total ERK 1,2 levels are fairly constant, increased ERK activity tends to occur in those tissues with oncogenic ras mutations.

\section{MEK Inhibition and Endogenous Gastrin mRNA Levels}

If activation of the Ras-Raf signal transduction pathway is in part responsible for induction of gastrin gene expression, inhibition of the ras pathway would likely result in decreased levels of gastrin message. A specific MEK inhibitor, PD 98059,48 was used to treat several colon cancer cell lines, from which total RN A was extracted and assayed for gastrin and cyclophilin message levels. SW 480, LoVo, and H ct116 cells, all of which have 


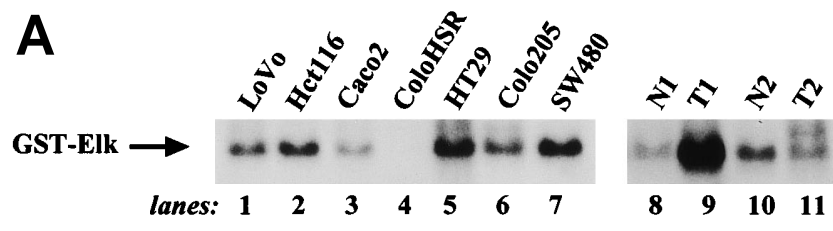

B Ras type
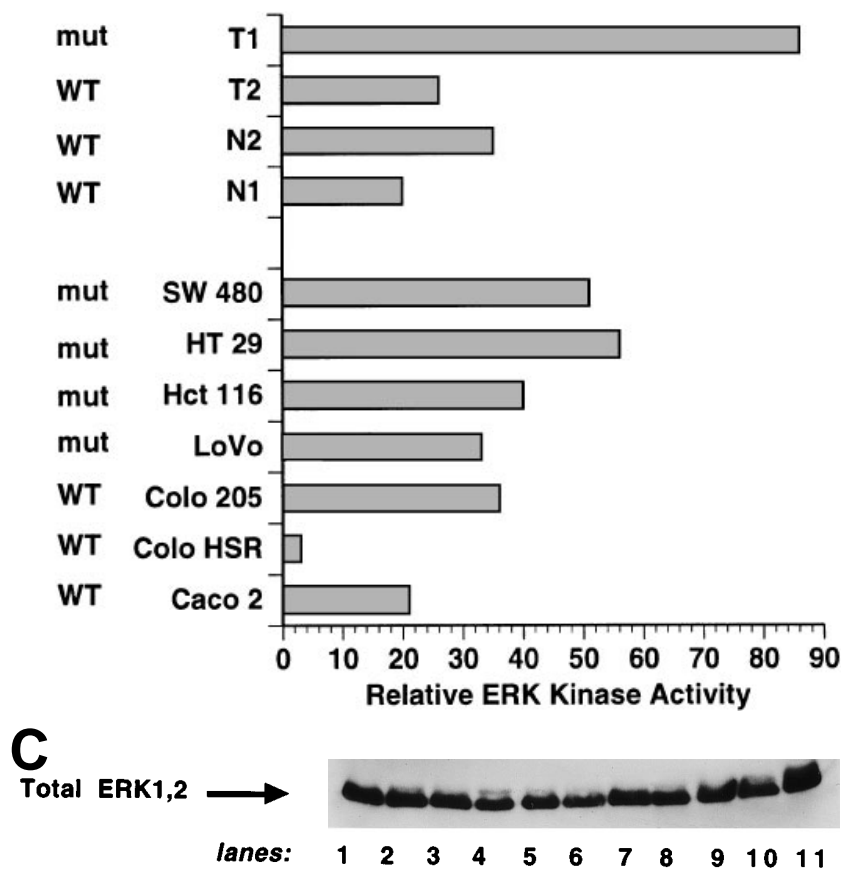

Figure 3. (A) ERK kinase activity of colon cancer cells and tissues. Whole-cell and tissue extracts ( $25 \mu \mathrm{g}$ protein each) from the same samples shown in Figure $2 A$ were used in a kinase assay as described in Materials and Methods. The phosphorylated substrate GST-Elk was electrophoresed, and the autoradiogram was obtained. $(B)$ Levels of phosphorylated GST-Elk. Densitometry of ERK kinase assay shown in A. (C) Levels of ERK 1,2 in colon cancer cells and tissues. Western blot of total ERK1,2 from colon cancer cell lines and tissue samples. Whole-cell protein extracts (100 $\mathrm{\mu g}$ each) were resolved by $10 \%$ SDS-PAGE, electrotransferred, and probed with anti-ERK2 as described in Materials and Methods. Numbering of lanes corresponds to those in $A$.

oncogenic ras mutations, were treated with 0,10 , and $100 \mu \mathrm{mol} / \mathrm{L}$ PD 98059. As shown in the RPA (Figure $1 A$ ), gastrin message levels were significantly lower in treated cells than those controls that were administered vehicle only. There was no significant variation in the cyclophilin message levels. The cyclophilin mR N A levels were normal ized across the samples, and gastrin-rel ative to-cyclophilin levels were determined for each sample and plotted as shown in Figure 1B. These results show that, when controlled for cyclophilin signal intensity, relative gastrin message levels were approximately $60 \%$ lower with MEK inhibition. It is noteworthy that gastrin expression in similarly treated ColoH SR cells did not decrease, indicating that the PD 98059 had no significant effect on the low basal activity of the Ras-Raf pathway (data not shown).
An indirect measure of kinase activity can be ascertained by probing a W estern blot with antisera specific for the phosphorylated forms of ERK. Protein extracts from SW 480, LoVo, and H ct116 cells were resolved and blotted by antisera specific for phosphorylated, active ERK 1,2 and total ERK 1,2 (Figure 1C). As shown in Figure 1C, W estern blot anal ysis confirmed that PD 98059 treatment led to a decrease in activated ERK $s$ without changing the overall ERK protein levels. These results support the conclusion that, in cells with oncogenic ras mutations, interference with the Raf-MEK-ERK pathway will down-regulate gastrin mRNA levels, yet not affect levels of the housekeeping gene cyclophilin.

\section{Oncogenic ras Activates Gastrin-Promoter, Luciferase-Reporter Genes}

Transient transfection experiments with ColoH SR cells, which are ras wild type and have low endogenous gastrin expression, were performed to directly examine the transcriptional effects of oncogenic ras on the gastrin gene promoter (Figure 4). ColoH SR cells were cotransfected with neomycin or oncogenic ras expression vectors and a gastrin-promoter, luciferase-reporter gene containing 200 or 1300 base pairs of gastrin 5'-flanking sequence. Transfection of an $\mathrm{H}$-ras $\mathrm{s}_{61 \text { Leu }}$ expression vector stimulated expression of cotransfected gastrin-promoter, luciferase-reporter genes 6-8-fold compared with cells expressing the control neomycin vector. Both lengths of the gastrin promoter seemed to be equally activated,

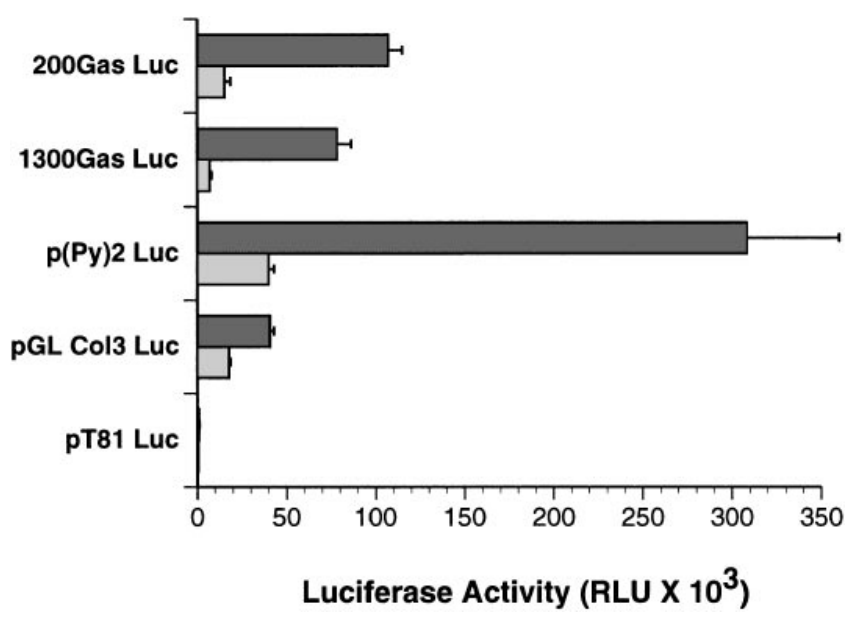

Figure 4. Oncogenic ras activation of gastrin-luciferase transcription in ColoHSR cells. Cells were transfected with pZip H-ras ${ }_{61 \mathrm{~L}}$ (圆) or pZip neomycin $(\square)$ expression vectors $(0.25 \mu \mathrm{g} /$ well) and a reporter plasmid $(1 \mu \mathrm{g})$ by a $\mathrm{CaPO}_{4}$ transient transfection method as noted. A polyoma viral promoter vector $\mathrm{p}(\mathrm{Py})_{2} \mathrm{Luc}$, with tandem ras responsive elements served as a positive control, whereas the minimal thymidine kinase promoter vector pT81Luc served as a negative control. A collagen gene promoter vector, pGLCol3Luc, containing 220 base pairs of 5 'flanking sequence, was included for comparison purposes. Luciferase activity was determined at 48 hours. Each data point represents the mean of triplicate determinations $( \pm S E M)$. RLU, relative light units. 
suggesting that the Ras-responsive cis-regulatory elements are within the proximal 200 bases of the gastrin 5'-flanking sequence. A polyoma viral promoter vector, p(Py)2Luc, with tandem Ras-responsive elements had approximately 8-fold induction. A collagen gene promoter vector, pGLCol3Luc, had 2-fold induction, whereas the minimal thymidine kinase promoter vector pT 81Luc was not induced. These results suggest that oncogenic ras can stimulate gastrin transcriptional activity in a genespecific manner. It is noteworthy that similar results were obtained with transfection of the oncogenic $\mathrm{K}$-ras $12 \mathrm{Val}$ vector (data not shown), indicating that both forms of oncogenic ras can induce gastrin.

Because oncogenic Ras can act along several kinase pathways, ${ }^{49}$ the effect of activated Raf on gastrinluciferase expression was examined next. As shown in Figure 5, transfection of ColoH SR cells with an expression vector for a constitutively active form of $R$ af, $p Z I P$ rafCAAX, resulted in 7-10-fold stimulation of gastrinluciferase expression. Again, thepositive control p(Py)2Luc was stimulated, but the collagen and thymidine kinase promoter vectors were not. These results suggest that $R$ as stimulation of gastrin transcriptional activity is mediated through the R af-MEK -ERK pathway.

To confirm the specificity of ras stimulation of gastrin promoter activity, ColoH SR cells were cotransfected with pZip vectors expressing $\mathrm{H}$-ras 61 Leu, dominant negative kinases, and the 200 gastrin-luciferase reporter gene. The effects on gastrin-luciferase expression by the cotransfected expression vectors are shown in Figure6. Coexpression of $\mathrm{H}$-ras 61 Leu with either dominant negative vectors for raf or ERK 1,2 resulted in substantial inhibition of the ras effect on gastrin-luciferase expression. Dominant negative vectors for rho and rac, which are collateral

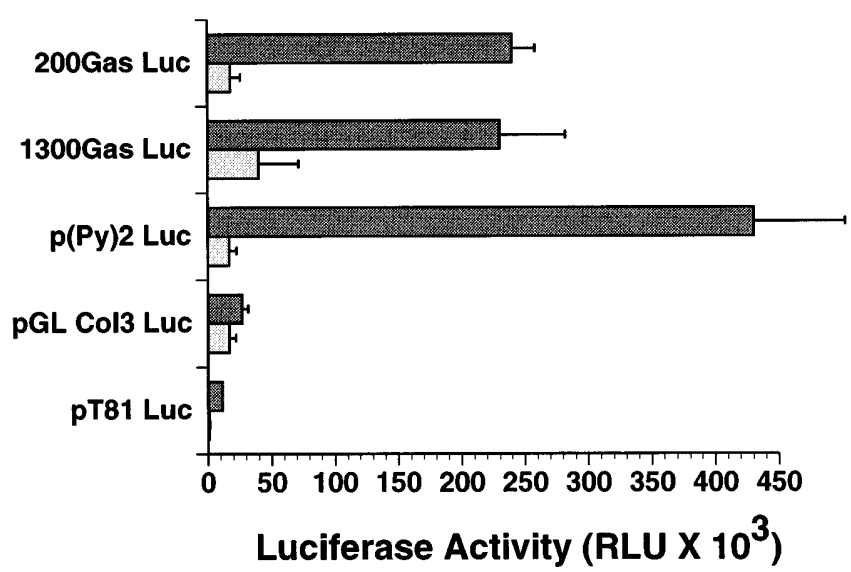

Figure 5. raf CAAX activates gastrin-luciferase trans cription in ColoHSR cells. Cells were transfected with pZip rafCAAX $(\mathbf{\square})$ or pZip neomycin ( $\square)$ expression vectors $(0.5 \mu \mathrm{g} /$ well) and a reporter plasmid (1 $\mu \mathrm{g} /$ well) as described in Materials and Methods. After 48 hours, cells were harvested for luciferase assays, and results of triplicate determinations are shown $( \pm$ SEM). RLU, relative light units. ras-associated pathways, had no effect on ras stimulation of gastrin-luciferase expression. These results and those in the previous figure are consistent with the following: the transcriptional activation of gastrin by oncogenic $R$ as is mediated principally through the R af-MEK -ERK signaling pathway.

B ecause oncogenic R as apparently increases R af-M EK ERK pathway activity and drives gastrin transcription, then one would predict that inhibition of ERK $s$ would have a greater effect on ras-transformed cells than those that are ras wild type. To test this hypothesis, plasmids for dominant negative ERK kinases or the negative control neomycin were cotransfected with gastrinluciferase reporter genes into ras mutant cell lines LoVo and $\mathrm{Hct} 116$ and a ras wild-type cell line ColoHSR. Unlike the experiment shown in Figure 6, an oncogenic ras expression vector was not cotransfected. As shown in Figure 7, both the ras mutant cell lines experienced a $>60 \%$ decrease in gastrin-Iuciferasetranscriptional activity with the presence of dominant negative ERKS. H owever, the ras wild-type cell line was not significantly affected by the dominant negative ERK $\mathrm{s}$. These results were corroborated by treating $\mathrm{Hct} 116$, LoVo, and ColoH SR cells with PD 98059 and assaying the resultant gastrin-luciferase transcriptional activity (data not shown). Gastrin-luciferase activity decreased $50 \%$ in the ras mutant cells but was not affected in the ras wild-type ColoH SR. Such findings showing that specific inhibitors of the Ras-Raf pathway down-regulate gastrin-luciferase activity support the conclusion that oncogenic Ras induces gastrin gene expression through transcriptional activation of the gastrin promoter.

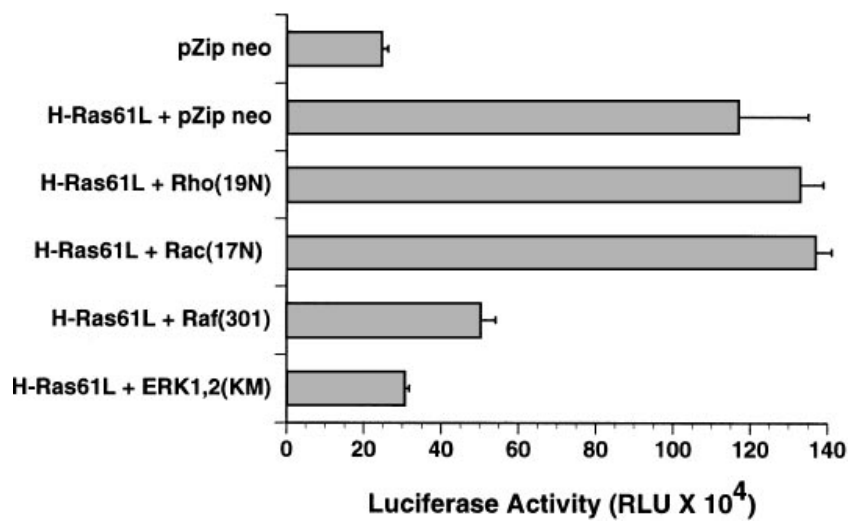

Figure 6. $\operatorname{raf}(301)$ and $E R K 1,2(\mathrm{KM})$ dominant negative kinases partially block $\mathrm{H}$-ras ${ }_{61 \mathrm{~L}}$ activation of gastrin-luciferase transcription in ColoHSR cells. Cells were cotransfected with pZip H-ras ${ }_{61 L}$ or pZip neomycin $(0.25 \mu \mathrm{g} /$ well $)$, a dominant negative kinase expression vector $(0.5 \mu \mathrm{g} /$ well), and the 200 Gas Luc reporter plasmid (1 $\mu \mathrm{g} / \mathrm{well})$. Cells were harvested at 48 hours for luciferase assays, and results of triplicate determinations are shown $( \pm S E M)$. RLU, relative light units. 


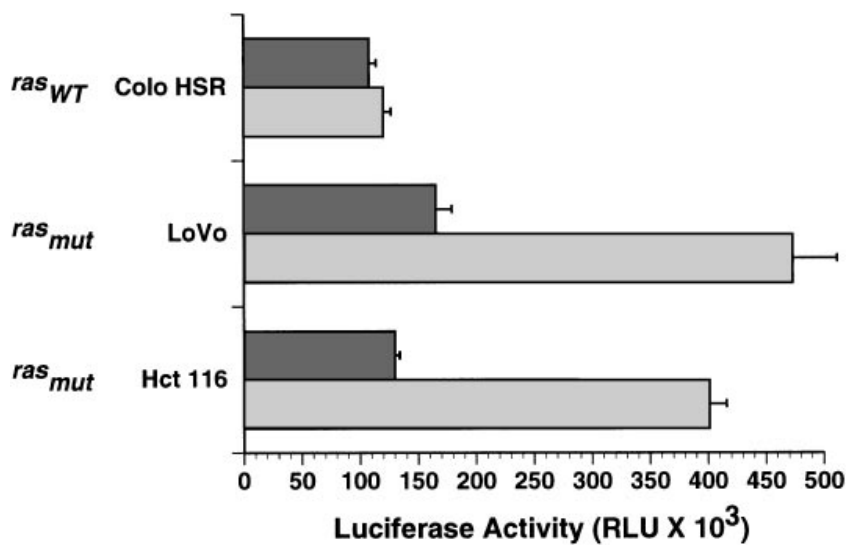

Figure 7. ERK1,2 (KM) dominant negative kinases cause a decrease in gastrin-luciferase transcriptional activity in ras mutant cells but not in ras wild-type cells. Cells were cotransfected with the 1300 gastrinluciferase reporter plasmids $(1 \mu \mathrm{g} /$ well) and expression vectors $(0.5$

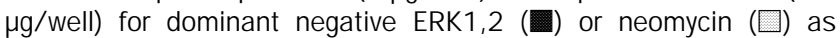
described in Materials and Methods. Cells were harvested at 48 hours for luciferase assays, and results of triplicate determinations are shown $( \pm \mathrm{SEM})$.

\section{Discussion}

Several studies have noted that colon cancer tumors often have increased levels of gastrin peptides, particularly incompletely processed forms. ${ }^{14,15,18} \mathrm{~N}$ ormal gastrin expression in the colon appears to be much higher during fetal development than after maturity. ${ }^{17} \mathrm{H}$ ence, the elevated expression of gastrin in colon cancer likely occurs through oncofetal transcriptional mechanisms, which to date have not been well characterized. The results of this study establish that oncogenic activation of the $R$ as signal transduction pathway induces gastrin gene expression. This evidence is based on the following: (1) a cl ose correlation between the presence of oncogenic K -ras mutations and increased gastrin message levels, (2) the down-regulation of endogenous gastrin message levels in cells treated with a specific MEK inhibitor, (3) the stimulation of gastrin transcriptional activity by activated oncogenic ras or raf, and (4) the ability of specific inhibitors of the Ras-Raf pathway to interfere with gastrin transcriptional activation. This is the first evidence that gastrin is a ras-responsive gene and that $R$ as is acting on the gastrin promoter through a R af-MEK -ERK pathway.

Oncogenic ras is known to induce the expression of other growth factors, such as heparin-binding EGF, ${ }^{29}$ vascular endothelial growth factor, ${ }^{50}$ and TG F- $\alpha .{ }^{28} \mathrm{H}$ epa rin-binding EGF appears to be an early-response gene responding to $R$ af induction within several hours. ${ }^{29}$ The transcriptional mechanism of $R$ as- $R$ af induction of heparin-binding EGF expression involves ERK phosphoryla tion of an Ets-2 transcription factor and its binding to a composite AP-1/Ets site in the heparin-binding EGF promoter. ${ }^{51}$ In contrast, the gastrin gene promoter does not appear to have consensus motifs for AP-1 response elements (Boel et al..$^{52}$ and unpublished observations, December, 1997). Of course, it is possible that AP-1 or Ets transcription factors are acting through nonconsensus binding sites. ${ }^{53}$ Likewise, a study by Marks et al. indicates that EGF stimulation of gastrin transcriptional activity in pituitary cells depends in part on c-fos expression, suggesting a rol efor A P-1. ${ }^{54}$ In addition, they have discovered that in gastric and pituitary cell lines, EGF stimulation of gastrin transcription is mediated through a novel GC-rich proximal cis-regulatory gastrin EGF response element. ${ }^{55}$ Because the 200 -base pair gastrin-luciferase reporter gene is ras responsive (Figure 5), it is likely that the ras-response elements are located in the proximal gastrin promoter and may include gastrin EG F response element, as well as other known el ements. Further studies are indicated to identify ras-responsive el ements of the gastrin promoter and to determine the transcriptional mechanism of induction.

It is also possible that ras induction of gastrin is mediated indirectly through other cytokines or growth factors. For example, ras could induce TGF- $\alpha$ expression, which in turn stimulates gastrin expression through an autocrine mechanism. Several studies have shown that ras induction of TGF- $\alpha$ expression in rat intestinal epithelial cells leads to an autocrine loop of TGF- $\alpha$ growth stimulation. ${ }^{28,56} \mathrm{H}$ owell et al. have linked gastrin and TGF- $\alpha$ by showing that gastrin message levels in $\mathrm{H}$ ctl16 cells fluctuate according to autocrine TGF- $\alpha$ stimulation. ${ }^{20}$ They found that when the TGF- $\alpha$ autocrine loop was interrupted by expression of an antisense TGF- $\alpha$ message, gastrin mR N A levels decreased. $H$ owever, when Baldwin and Zhang analyzed gastrin and T GF- $\alpha$ mR N A levels in seven col on cancer cell lines, they did not find a close correlation between the two factors. ${ }^{57} \mathrm{H}$ ence, it is possible that stimulation of gastrin gene expression occurs as a secondary event in response to ras induction of another growth factor in addition to TG F- $\alpha$.

We found that, although total ERK levels were equival ent among all the cell lines tested, increased ERK activity generally correlated with the presence of oncogenic ras mutations (see Figure 3 ). H owever, this association between ERK activity and ras status was not as strong as that of oncogenic ras and gastrin induction. $\mathrm{N}$ onethel ess, these results are consistent with oncogenic ras causing constitutive activation of the R af-MEK -ERK pathway. ${ }^{33,58}$ However, Licato et al. recently reported that, although ERK and Jun kinase activities were increased in col on tumors of mice treated with dimethylhydrazine, there was no direct correlation between the ERK activity and ras status of the tumor. ${ }^{59} \mathrm{Although}$ one might expect that ERK activity should al ways correlate 
with ras status, it is likely to be more complicated in that other kinases and phosphatases affect the R af-MEK -ERK pathway. ${ }^{60-62}$ Thus, overall ERK activity may be modulated by multiple signal pathways and not limited to the state of Ras activation. It will be important to systematically study larger numbers of tumor samples to determine the degree of correlation between ERK activities and ras status.

Several studies have noted that gastrin expression is not uniformly increased in colon cancer tumors. ${ }^{18,57} \mathrm{~A}$ study by Finley et al. noted that, of the colon tumors assayed, more than half of the tumor cells stained for gastrin and 2 of 4 tumors had detectable gastrin $\mathrm{mRN} A .{ }^{18}$ The results of the current study indicate that gastrin expression is indeed variable but dependent on oncogenic ras stimulation. This correlation fits the observations that oncogenic K-ras mutations occur in about $50 \%$ of the colon tumors. ${ }^{63}$ Some studies indicate that tumors with oncogenic $\mathrm{K}$-ras mutations are more aggressive and associated with a shorter mean survival time. ${ }^{64,65}$ As Singh et al. and Wang et al. have shown, induction of gastrin expression would give the tumors a significant growth advantage ${ }^{11,13}$ Although it remains to be determined whether all colon tumors with oncogenic $\mathrm{K}$-ras mutations have increased gastrin expression, it is likely that assessment of both ras status and relative gastrin expression will provide useful prognostic information. Such information may be critical for determining which patients with colon cancer will benefit from antigastrin therapy. ${ }^{11}$

\section{References}

1. Johns on LR. New aspects of the trophic action of gastrointestinal hormones. Gastroenterology 1977;72:788-792.

2. Walsh JH. Role of gastrin as a trophic hormone. Digestion 1990;47(suppl 1):11-16.

3. Smith J, Solomon T. Effects of gastrin, proglumide, and somatostatin on growth of human colon cancer. Gastroenterology 1988;95: 1541-1548.

4. Watson S, Durrant L, Crosbie J, Morris D. The in vitro growth response of primary human colorectal and gastric cancer cells to gastrin. Int J Cancer 1989;43:692-696.

5. Winsett O, Townsend C, Glass E, Thomps on J. Gastrin stimulates growth of colon cancer. Surgery 1986;99:302-307.

6. Lamote J, Willems G. Stimulating effect of pentagastrin on cancer cell proliferation kinetics in chemically induced colon cancer in rats. Regul Pept 1988;20:1-9.

7. Hoosein N, Kiener P, Curry R, Rovati L, McGilbra D, Brattain M. Antiproliferative effects of gastrin receptor antagonists and antibodies to gastrin on human colon carcinoma cell lines. Cancer Res 1988;48:7179-7183.

8. Wats on SA, Michaeli D, Grimes S, Morris T, Crosbee D, Wilkinson M, Robinson G, Robertson J, Steele R, Hardcastle J. Anti-gastrin antibodies raised by gastrimmune inhibit growth of the human colorectal tumour AP5. Int J Cancer 1995;61:233-240.

9. Beauchamp R, Townsend C, Singh P, Glass E, Thompson J. Proglumide, a gastrin receptor antagonist, inhibits growth of colon cancer and enhances survival in mice. Ann Surg 1985;202:303307.
10. Romani R, Howes LG, Morris DL. Gastrin receptor antagonist $\mathrm{Cl}-988$ inhibits growth of human colon cancer in vivo and in vitro. Aust N ZJ Surg 1996;66:235-237.

11. Singh P, Owlia A, Varro A, Dai B, Rajaraman S, Wood T. Gastrin gene expression is required for the proliferation and tumorigenicity of human colon cancer cells. Cancer Res 1996;56:41114115.

12. Rehfeld JF. Gastrin and colorectal cancer: a never-ending dispute? Gastroenterology 1995;108:1307-1310.

13. Wang T, Koh T, Varro A, Cahill R, Dangler C, Fox J, Dockray G. Processing and proliferative effects of human progastrin in transgenic mice. J Clin Invest 1996;98:1918-1919.

14. Van Solinge WW, Nielsen FC, Friis-Hansen L, Falkmer UG, Rehfeld $J \mathrm{~F}$. Expression but incomplete maturation of progastrin in colorectal carcinomas. Gastroenterology 1993;104:1099-1107.

15. Nemeth J, Taylor B, Pauwels S, Varro A, Dockray G. Identification of progastrin derived peptides in colorectal carcinoma extracts. Gut 1993;34:90-95.

16. Ciccotosto GD, McLeish A, Hardy KJ, Shukes A. Expression, processing, and secretion of gastrin in patients with colorectal carcinoma. Gastroenterology 1995;109:1142-1153.

17. Luttichau HR, Van Solinge WW, Nielsen FC, Rehfeld JF. Developmental expression of the gastrin and cholecystokinin genes in rat colon. Gastroenterology 1993;104:1092-1098.

18. Finley GG, Koski RA, Melhem MF, Pipas JM, Meisler Al. Expression of the gastrin gene in the normal human colon and colorectal adenocarcinoma. Cancer Res 1993;53:2919-2926.

19. Godley J, Brand S. Regulation of the gastrin promoter by epidermal growth factor and neuropeptides. Proc Natl Acad Sci USA 1989;86:3036-3040.

20. Howell GM, Ziober BL, Humphrey LE, Willson J, Sun L, Lynch M, Brattain M. Regulation of autocrine gastrin expression by the TGF alpha autocrine loop. J Cell Physiol 1995;162:256-265.

21. Aaronson S. Growth factors and cancer. Science 1991;254:11461153.

22. Baserga R. Oncogenes and the strategy of growth factors. Cell 1994;79:927-930.

23. White MA, Nicolette $C$, Minden A, Polverino A, Van Aelst L, Karin $M$, Wigler M. Multiple Ras functions can contribute to mammalian cell transformation. Cell 1995;80:533-541.

24. Hill CS, Treisman R. Transcriptional regulation by extracellular signals: mechanisms and specificity. Cell 1995;80:199-211.

25. Cowley S, Paterson H, Kemp P, Marshall C. Activation of MAP kinase kinase is necessary and sufficient for $\mathrm{PC} 12$ differentiation and for transformation of NIH 3T3 cells. Cell 1994;77:841852.

26. Oldham SM, Clark GJ, Gangarosa LM, Coffey RJ Jr, Der CJ. Activation of the Raf-1/ MAP kinase cascade is not sufficient for Ras transformation of RIE-1 epithelial cells. Proc Natl Acad Sci USA 1996;93:6924-6928.

27. Sasaoka T, Langlois WJ, Leitner JW, Draznin B, Olefsky JM. The signaling pathway coupling epidermal growth factor receptors to activation of p21ras. J Biol Chem 1994;269:32621-5262.

28. Filmus J, Shi W, Spencer T. Role of transforming growth factor alpha (TGF-alpha) in the transformation of ras-transfected rat intestinal epithelial cells. Oncogene 1993;8:1017-1022.

29. McCarthy SA, Samuels ML, Pritchard CA, Abraham JA, McMahon $M$. Rapid induction of heparin-binding epidermal growth factor/ diphtheria toxin receptor expression by Raf and Ras oncogenes. Genes Dev 1995;9:1953-1964.

30. Sambrook J, Fritsch EF, Maniatis T. Molecular cloning: a laboratory manual. 2nd ed. Cold Spring Harbor, NY: Cold Spring Harbor Press, 1989.

31. Ausubel F, Brent R, Kingston R, Moore D, Seidman J, Smith J, Struhl K, eds. Current protocols in molecular biology. Wiley, 1997.

32. Marais R, Wynne J, Treisman R. The SRF accessory protein Elk-1 
contains a growth factor-regulated transcriptional activation domain. Cell 1993;73:381-393.

33. Westwick J, Cox A, Der C, Cobb M, Hibi M, Karin M, Brenner D. Oncogenic Ras activates $c-J$ un via a separate pathway from the activation of extracellular signal-regulated kinases. Proc Natl Acad Sci USA 1994;91:6030-6034.

34. Alam J, Cook J. Reporter genes: application to the study of mammalian gene transcription. Anal Biochem 1990;188:245254.

35. Bradford MM. A rapid and sensitive method for the quantitation of microgram quantities of protein utilizing the principle of proteindye binding. Anal Biochem 1976;72:248-254.

36. Tillots on LG, Wang TC, Brand SJ . Activation of gastrin transcription in pancreatic insulinoma cells by a CACC promoter element and a $70-k D a$ sequence-specific DNA-binding protein. J Biol Chem 1994;269:2234-2240.

37. Galang C, Der C, Hauser C. Oncogenic ras can induce transcriptional activation through a variety of promoter elements, including tandem c-Ets-2 binding sites. Oncogene 1994;9:2913-2921.

38. Nehls MC, Rippe RA, Veloz L, Brenner DA. Transcription factors nuclear factor I and Spl interact with the murine collagen alpha1(I) promoter. Mol Cell Biol 1991;11:4065-4073.

39. Nordeen SK. Luciferase reporter gene vectors for analysis of promoters and enhancers. Biotechniques 1988;6:454-457.

40. Buss J, Solski P, Schaeffer J, MacDonald M, Der C. Activation of the cellular proto-oncogene product $\mathrm{p} 21$ ras by addition of $a$ myristylation signal. Science 1989;243:1600-1603.

41. Khosravi-Far R, Solski P, Clark G, Kinch M, Der C. Activation of $\mathrm{Rac1}$, RhoA, and mitogen-activated protein kinases is required for ras transformation. Mol Cell Biol 1995;15:6443-6453.

42. Williams N, Roberts $T$, Li P. Both p21ras and pp60x-src are required, but neither alone is sufficient to activate the Raf-1 kinase. Proc Natl Acad Sci 1992;89:2922-2926.

43. Robbins $D$, Zhen $E$, Cheng $M, X u$ S, Vanderbilt $C$, Ebert D, Garcia C, Dang A, Cobb M. Regulation and properties of extracellular signal-regulated protein kinases 1, 2, and 3. J Am Soc Nephrol 1993;4:1104-1110.

44. Brand SJ, Wang TC. Gastrin gene expression and regulation in rat islet cell lines. J Biol Chem 1988;263:16597-16603.

45. Brand SJ, Fuller PJ. Differential gastrin gene expression in rat gastrointestinal tract and pancreas during neonatal development. J Biol Chem 1988;263:5341-5347.

46. Sepp-Lorenzino L, Ma Z, Rands E, Lacave R, Boudghene $F$, Breittmayer F, Languille 0 , Roland J, Bernaudin J. A peptidomimetic inhibitor of farnesyl: protein transferase blocks the anchorage-dependent and -independent growth of human tumor cell lines. Cancer Res 1995;55:5302-5309.

47. Urban T, Ricci S, Grange JD, Kohl N, Gibbs J, Oliff A, Rosen N. Detection of c-Ki-ras mutation by PCR/ RFLP analysis and diagnosis of pancreatic adenocarcinomas [see comments]. J Natl Cancer Inst 1993;85:2008-2012.

48. Dudley D, Pang L, Decker S, Bridges A, Saltiel A. A synthetic inhibitor of the mitogen-activated protein kinase cascade. Proc Natl Acad Sci USA 1995;92:7686-7689.

49. Clark G, Westwick J, Der C. p120 GAP modulates Ras activation of Jun kinases and transformation. J Biol Chem 1997;272:16771681.

50. Rak J, Mitsuhashi Y, Bayko L, Filmus J, Shirasawa S, Sasazuki T, Kerbel R. Mutant ras oncogenes upregulate VEGF/VPF expression: implications for induction and inhibition of tumor angiogenesis. Cancer Res 1995;55:4575-4580.

51. McCarthy SA, Chen D, Yang BS, Garcia Ramirez J, Cherwinski $H$, Chen X, Klags brun M, Hauser C, Ostrowski M, McMahon M. Rapid phosphorylation of Ets-2 accompanies mitogen-activated protein kinase activation and the induction of heparin-binding epidermal growth factor gene expression by oncogenic Raf-1. Mol Cell Biol 1997;17:2401-2412.
52. Boel E, Vuust J, Norris F, Norris K, Wind A, Rehfeld J, Marcker K. Molecular cloning of human gastrin CDNA: evidence for evolution of gastrin by gene duplication. Proc Natl Acad Sci USA 1983;80: 2866-2869.

53. Petrak D, Memon SA, Birrer MJ, Ashwell JD, Zacharchuk CM. Dominant negative mutant of C-J un inhibits NF-AT transcriptional activity and prevents IL-2 gene transcription. J Immunol 1994;153: 2046-2051.

54. Marks P, lyer G, Cui $Y$, Merchant J. Fos is required for EGF stimulation of the gastrin promoter. AmJ Physiol 1996;271:G942G948.

55. Merchant JL, Demediuk B, Brand SJ. A GC-rich element confers epidermal growth factor responsiveness to transcription from the gastrin promoter. Mol Cell Biol 1991;11:2686-2696.

56. Gangarosa LM, Sizemore N, Coffey RJ. A Raf-independent epidermal growth factor receptor autocrine loop is necessary for Ras transformation of rat intestinal epithelial cells. J Biol Chem 1997;272:18926-18931.

57. Baldwin GS, Zhang Q-X. Measurement of gastrin and transforming growth factor alpha messenger RNA levels in colonic carcinoma cell lines by quantitative polymerase chain reaction. Cancer Res 1992;52:2261-2267.

58. Liang P, Averboukh L, Zhu W, Pardee AB. Ras activation of genes: Mob-1 as a model. Proc Natl Acad Sci USA 1994;91:1251512519.

59. Licato LL, Keku TO, Wurzelmann JI, Murray SC, Woosley JT, Saudler RS, Brenner DA. In vivo activation of mitogen-activated protein kinases in rat intestinal neoplasia. Gastroenterology 1997;113:1589-1598.

60. Ueda Y, Hirai S, Osada S, Suzuki A, Mizuno K, Ohno S. Protein kinase $C$ delta activates the MEK-ERK pathway in a manner independent of Ras and dependent on Raf. J Biol Chem 1996;271: 23512-23519.

61. Enslen H, Tokumitsu H, Stork PJ, Davis RJ, Soderling TR. Regulation of mitogen-activated protein kinases by a calcium/ calmodulin-dependent protein kinase cascade. Proc Natl Acad Sci USA 1996;93:10803-10808.

62. Hunter T. Protein kinases and phosphatases: the yin and yang of protein phosphorylation and signaling. Cell 1995;80:225-236.

63. Fearnon RR, Vogelstein B. A genetic model for colorectal tumorigenesis. Cell 1990;61:759-767.

64. Bell SM, Scott N, Cross D, Sagar P, Lewis F, Blair G, Taylor G, Dixon M, Quirke P. Prognostic value of p53 overexpression and c-Ki-ras gene mutations in colorectal cancer. Gastroenterology 1993;104:57-64.

65. Span M, Moerkerk P, De Goeij A, Arends J. A detailed analysis of $\mathrm{K}$-ras point mutations in relation to tumor progression and survival in colorectal cancer patients. Int J Cancer 1996;69:241245.

Received December 16, 1997. Accepted August 4, 1998.

Address requests for reprints to: Loyal G. Tillotson, M.D., Ph.D., CB 7038, Room 148, Glaxo Building, University of North Carolina, Chapel Hill, North Carolina 27599-7038, e-mail: loyal_tillotson@ unc. edu; fax: (919) 966- 7468.

Supported by grant R29 DK49860 from the National Institutes of Health, a grant from the Glaxo Institute of Digestive Health Basic Research, and grant P30DK34987 from the Center for Gastrointestinal Biology and Disease.

The authors thank Drs. Channing Der (kinase expression vectors and $p(P y) 2 L u c)$, Richard Rippe (pGL Col3 Luc), and Timothy Wang (pGem gastrin exon 2) for providing plasmids; Drs. David Brenner, Cyndi Bradham, Laura Licato, and Martin McMahon for helpful discussions; Dr. Shrikant Bangdiwala for advice about statistical analysis; and Dr. Kevin Behrns (University of North Carolina) and Tissue Procurement facilities at the Lineberger Cancer Center (University of North Carolina) and Massachusetts General Hospital for providing surgical specimens. 